\title{
Navigating Non-Linear Art Histories: Sophie Orlando's Case Studies of British Black Art
}

Ella S. Mills

\section{(2) OpenEdition}

1 Journals

\section{Electronic version}

URL: http://journals.openedition.org/imagesrevues/4841

DOI: 10.4000/imagesrevues.4841

ISSN: 1778-3801

\section{Publisher:}

Centre d'Histoire et Théorie des Arts, Groupe d'Anthropologie Historique de l'Occident Médiéval, Laboratoire d'Anthropologie Sociale, UMR 8210 Anthropologie et Histoire des Mondes Antiques

\section{ELECTRONIC REFERENCE}

Ella S. Mills, “Navigating Non-Linear Art Histories: Sophie Orlando's Case Studies of British Black Art", Images Re-vues [Online], Hors-série 6 | 2018, Online since 06 August 2018, connection on 31 January 2021. URL: http://journals.openedition.org/ imagesrevues/4841 ; DOI: https://doi.org/10.4000/imagesrevues.4841

This text was automatically generated on 31 January 2021.

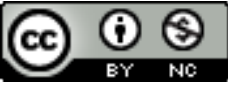

Images Re-vues est mise à disposition selon les termes de la Licence Creative Commons Attribution -

Pas d'Utilisation Commerciale 4.0 International. 


\title{
Navigating Non-Linear Art Histories: Sophie Orlando's Case Studies of British Black Art ${ }^{1}$
}

\author{
Ella S. Mills
}

How I wish Sophie Orlando's book, British

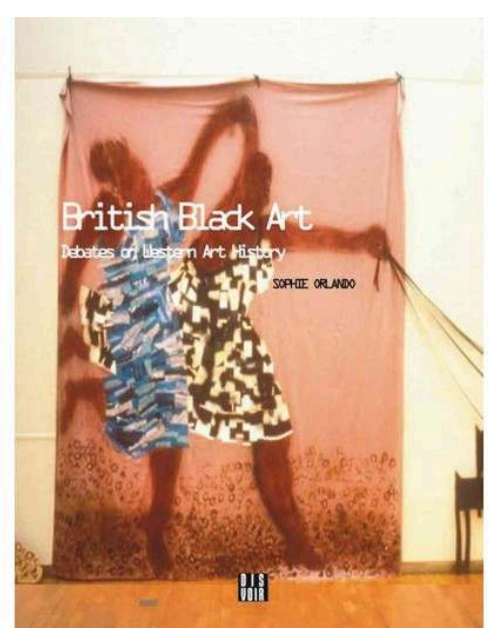

Black Art: Debates on Western Art History, had been in print ten years ago when I began my own research into what has now become known (at least in Britain) as a Black Arts Movement of the $1980 \mathrm{~s}^{2}$. This was a movement that absolutely defined a decade in the histories of British art, producing some of the most powerful visual arts in recent years by artists too numerous to list here. In her book Orlando chooses to highlight artworks by Lubaina Himid, Eddie Chambers, Rasheed Araeen, Sonia Boyce, and Chila Kumari Burman. The Black Arts Movement was an incredible energy of active and passionate creativity comprising individuals, collectives and collaborators, many of whom were also animateurs, "individuals who took on more than one role: artists who curate, write, advocate, and do archival work as well $»^{3}$. A deeply complicated moment in art history with ongoing debates and politics both "internal » and " external " to the movement, for years there has been a lack of substantial, sustained critical analysis and 
well-established discourse around the practice of British Black Artists and their impact on broader landscapes of British art history and cultural memory. In terms of accessible scholarly documentation it was not until, as Orlando reminds us, Shades of Black: Assembling Black Art in 1980s Britain was published in 2001 that a collective, focused attempt to re-visit the 1980 s was produced ${ }^{4}$. This book documented a two-day conference that took place at Duke University, North Carolina. Orlando notes that the British organizers, photographer David A. Bailey, artist Sonia Boyce, and English Literature professor at Duke, Ian Baucom, identified an « urgent need to engage in a critical analysis » of the artworks and attention to « documentation and archiving since the end of the 1980s $»^{5}$. Despite the demand articulated by those involved in Shades of Black (2001), artists, curators, arts administrators and academics, it is only recently that critical engagement has gained significant traction and momentum. Orlando's book is one response to that call voiced during Shades of Black, and is situated within this current surge of reflective and analytical activity.

One of the first items to note regarding Orlando's book, which may be of particular interest to those unfamiliar with this period in British art history, is the title. Briefly examining African and Asian artists living and working in Britain in the 1960s and 1970s, Orlando's work principally addresses the 1980s movement of British Black Art, and later 1990s activity. Although this specific period is not clearly defined in her book title, British Black Art: Debates on Western Art History, this attention to two specific decades is justified through Orlando's statement that «Black Art » is a term directly associated with the 1980s (and somewhat beyond):

The artists linked to the Afro-Caribbean and Asian diasporas must be distinguished from « Black Art » or « British Black Art », the artistic movement born in the 1980s' [as] the term «Black » in British English connotes a political position shared by immigrants and the children of immigrants living in a postcolonial, European territory ${ }^{6}$.

«Black» in terms of art was indeed a political statement for the younger, emerging artists of the 1980s, the first generation of « British Black Artists » born or raised in the UK and graduating from British arts institutions. For many, however, of an older generation of African and Asian artists, born in colonized countries and who came to the UK as older students, this was a troubling descriptor that did not hold the same meaning.

4 The surge of creative activity by British Black Artists during the 1980s has been notoriously tricky to discuss and define for art writers. British cultural theorist Stuart Hall described the moment at the Shades of Black conference, as: " not a unified, coherent, or organized phenomenon, this "movement" (if something so loose can be called such) [...] challenges the institutional spaces, established circuits, and validated canons of critical achievement of the metropolitan mainstream $»^{7}$. There is no doubt there existed an emergent collective focus of energies from a community of African and Asian British artists, whose aims and agendas to make art and confront the British canon, frequently intersected with one another. That moment of the 1980s, however, also inevitably comprised distinct approaches, strategies, and styles of aesthetics and concepts between high numbers of artists located across Britain.

5 Likewise during the pivotal Shades of Black conference, British art historian Kobena Mercer spoke of «Iconography after Identity »:

Because so much of the writing [about British Black Artists] concentrates on the artist's biographical identity or the experience of exclusion in institutional practice, 
the more interesting problems and questions of interpretation concerning iconography and iconology tend to be continual pushed back and deferred. I would argue that critics and those directly interested in writing about art have now arrived at a point where you can no longer actually carry on like that ${ }^{8}$.

These were/are not only scholarly dilemmas external to the Black Arts Movement but a problematic present in much of the existing discussion by those « internal » to the period, including Mercer. Orlando proposes:

Many authors - often from the field of sociology [...] have contributed to defining the positions of the artists in the British Black Art movement (Stuart Hall, Hazel Carby, Paul Gilroy, Kobena Mercer) ${ }^{9}$.

Orlando clearly takes Mercer's call as a core motivator for the research in her study to engage with British Black Artists by drawing on methodologies of structuralism, formalism, post-structuralism and deconstruction, with a plan to "open up new pathways for interpreting these works $»^{10}$. I believe Orlando is successful in offering different approaches to engaging with British Black Artists compared to existing books in this field.

Orlando's book makes a timely and valuable contribution to these now rapidly evolving conversations, particularly with regard to her commitment from the outset to a critical dialogue with specific artworks and attempts to move away from a sociological framework. She details her intentions in her Introduction:

I systematically examine the relationships between the artistic tools specifically used in the artistic productions and how they belong to a place that is gendered, racial, and sexual and inscribe within a social class, combining the formalist heritage of poststructuralism with intersectionality [...] enabling me to move beyond a sociological reading of artists by engaging in an analysis of artistic forms, while taking account of the historicity of the socially situated construction of academic knowledge and artistic propositions ${ }^{11}$.

In carefully contextualizing her research Orlando acknowledges the complexities and difficulties in writing about an historically complicated period of visual arts production, displaying a great deal of respect for the work and the artists she includes. Orlando's French upbringing as described in the Foreword places the book between her own double migration - coming from two different Italian immigrant stories - and the term « Black » connoting a: « political position shared by immigrants and the children of immigrants living in a postcolonial, European territory $»^{12}$. Framing the book therefore as an « intersectional approach to the history of Western art » Orlando not only highlights her well placed position as an art historian in this field where migration and duality exists in many of the artworks, but she also acknowledges the fundamental characteristics of a Western art history that typically lacks an intersectional lens, i.e., hierarchical and exclusionary. Here I suggest that Orlando could perhaps have identified how her particular perspective on Intersectionality is one understanding amongst a variety of nuanced interpretations from which to draw. This would be helpful to the reader unfamiliar with the concept as there exists a variety of tensions and discussions involving " race ", sexuality, gender, class, nation, location, generation, and contradictory or challenging interpretations of the concept of intersectionality itself.

Organized over four chapters Orlando has thoughtfully laid out her research not in a chronological timeline as traditional art history books tend to do, but around themes and specific artworks: Chapter I - British Black Art; Chapter II - Deconstructing and 
Rethinking the Positions of $20^{\text {th }}$ Century Western Art; Chapter III - Artistic Tactics and New Internationalism; and Chapter IV - Political Cultures of the British Artistic Scenes.

Chapter I: British Black Art, gives some context to the 1980s period in which the first generation of British born (or raised from pre-school age) Black artists began carving out their spaces in the annals of British Art History. ${ }^{13}$ Orlando includes Claudette Johnson's presentation at the 1982 conference of the First National Black Art Convention and the absolutely pivotal role Johnson played - and other women artists in the early formations of a " movement ». I was thrilled to see Orlando include I came to dance (1982) by Johnson, whose artwork, and vital involvement in the Blk Art Group, is frequently underrepresented or folded out of sight (fig. 1) ${ }^{14}$.

Fig. 1

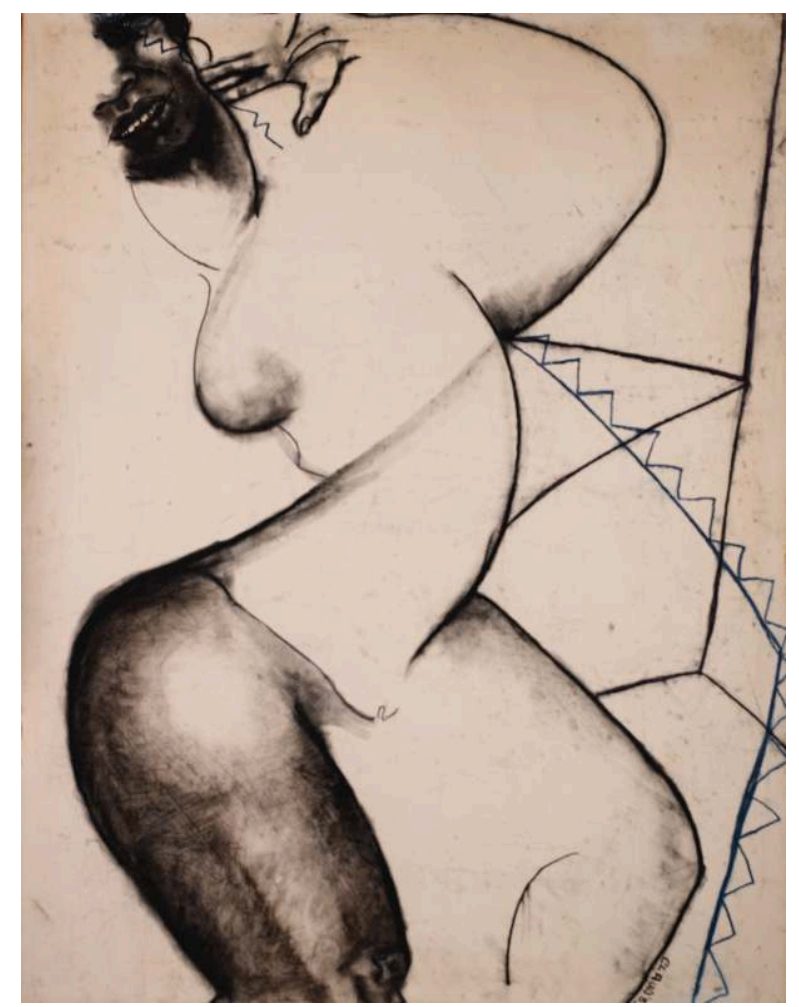

Claudette Johnson, I came to dance, pastels on paper, 1982. @ Claudette Johnson, Photo courtesy Denise Swanson

Chapter II - Deconstructing and Rethinking the Positions of $20^{\text {th }}$ Century Western Art focuses on Lubaina Himid and Eddie Chambers and the " way in which certain works "deconstruct" as this term was defined by poststructuralist philosophers [with both artists] analyzing the politics of the subject and of the artist subject within modernization and modernism $»^{15}$. It is always a joy to see attention given to Himid's artworks such as Freedom and Change (1984), and the relationship with Picasso (fig. 2). Building on the detailed discussions of Freedom and Change with modernism and modernity in Gilane Tawadros's essay, «Beyond the Boundary: The Work of Three Black Women Artists in Britain $",{ }^{16}$ Orlando comments that Himid « contextualizes and displaces the work of the Spanish painter [by] decentering the white subject, which is pushed into the margins....By placing two black women at the centre of the painting, she calls for a historicization of black peoples, while also suggesting a reflection on 
sexuality and its representations at a time when there were intense reflections on national identities (Britishness) $»^{17}$.

Fig. 2

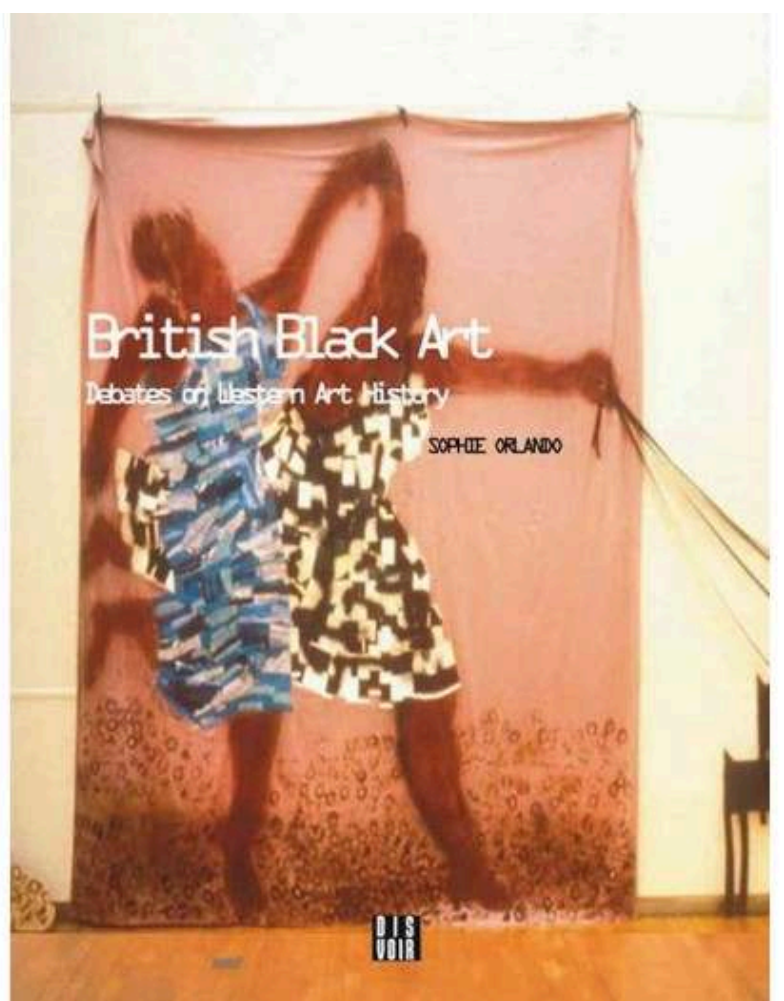

Sophie Orlando's book cover including Lubaina Himid, Freedom and Change, 1984 Boyce and Sarah Lucas ${ }^{18}$. Orlando proposes that "this chapter will focus on the congruence between the political and cultural changes that occurred between 1975 and 1989 and the artistic choices made by these two artists to reassess them in light of the notions of "cosmopolitan", "internationalism" and "new internationalism"19. Orlando's discussion of " gender-based identities » with regard to Boyce and Lucas is of particular interest $^{20}$.

Chila Kumari Burman's work is discussed in great detail in Chapter IV: Political Cultures of the British Artistic Scenes ${ }^{21}$. Orlando situates Kumari Burman as an artist whose critiques of "blackness » challenge the common trope of cultural studies being associated with Black Artists only. Orlando outlines the ways in which «Cultural studies must be understood as a common tool with which artists create in Great Britain; one that is well beyond the framework of British Black Art $»^{22}$. For Orlando, Kumari Burman's $"$ artistic odyssey interrogates identity politics from a Marxist and Feminist differentialist position that emerged in the 1970s and affirmed a Black feminist critique (Black Feminism), in order to deconstruct the popular and virile form of blackness especially in the USA ${ }^{23}$. Orlando highlights the multifaceted cultural influences for Kumari Burman's visual artworks, ranging from punk and blues music, to Marxist, and feminist theory, Afro-Caribbean poetry and feminist activism, further troubling ideas around the cultural journeys of being a British Black artist and British culture in general. 

timeline, avoiding the idea that a definitive number of artists associated with the period could be named in one exclusive space. This is a relief to see, and a key decision for her in negotiating the project of British Black Art: Debates on Western Art History. Orlando's aforementioned intersectional lens further highlights an awareness of representations of British Black Artists so frequently isolated as having a collective, singular aim and aesthetic. Similarly Orlando spotlights the range of writers and thinkers involved with the formation of a discourse around British Black Artists by drawing on a variety of scholars and fields throughout her book. Referencing, for example, not only artists, art historians, curators and critics, but also scholars of social histories of art, feminist studies, Black feminism, cultural studies, sociology, literature, politics, post-colonialism, gender studies, queer theory and film. This serves to illustrate that Orlando recognizes on the one hand the core multifaceted pluralism inherent in British Black Art, whilst also simultaneously acknowledging this interdisciplinary nature as being one of the core problematics in the endeavor of debating it.

Orlando has tracked down, listened, gathered and presented a careful selection of events, people and artworks and in so doing has documented stories and practices of several British Black Artists who are/have been folded out of sight from " official' narratives and canonized spaces of art history such as educational curricula, major scholarly publications, monographs, and artist retrospective exhibitions or one wo/ man shows. It is a shame the book is so short and does not allow Orlando extensive space to discuss and analyse more artworks. Having said that, her decision is successful to consider in-depth a selection of artists rather than attempt to offer a complete history or finite framework of critical analysis defining " key figures " of the movement. I also enjoy Orlando's decision to include so many artists not ordinarily associated with the idea and narratives of British Black Art such as Sarah Lucas, Tracey Emin and Jeremy Deller. It would have been refreshing to have had even more studies of Himid, Burman and Chambers as Orlando's interesting discussion makes the reader want to learn more. I think at this early stage of widely distributed scholarship it is a difficult task to balance the challenges put forth by Hall and Mercer in approaching this moment in art history. Orlando illustrates she has carefully considered those challenges while also providing a document brimming with names of artists and theorists. A point I would debate is Orlando's declaration that the Blk Art Group " founded the movement » of British Black Art in the $1980 \mathrm{~s}^{24}$. There is no doubt the Blk Art Group, and in particular their 1982 convention, was a fundamental dynamic element of the movement, especially the core role the women artists played. There were, however, countless creative people active on many levels of involvement, across geographical locations, with varying journeys who contributed to the development of a Black Arts Movement ${ }^{25}$. It is significant to see what histories are being told and who is featured in these current dialogues as there is a repetition of names and artworks that are beginning to be the "face » of a British Black Arts Movement. As such I think it is important to be mindful of the kind of narratives being presented in the art histories being (re)told.

Situated alongside the only other two major publications dedicated to this specific field, Orlando's book brings a new perspective to (re)visiting the 1980s and 1990s energies of British Black Art ${ }^{26}$. Shades of Black, and Eddie Chambers' Black Artists in British 
Art: A History Since the 1950s published in 2014, were both authored by people « internal " to the Black Arts Movement ${ }^{27}$. Orlando, however, is coming to the moment as an outsider, an art historian with access to the histories via archives and interviews and with no first hand experience of the period. Shades of Black was the first real collective attempt to revisit the debates of the time and problematics around the development of a discourse, whereas Chambers' book seeks to plot out some of the narratives of African and Asian British artists, setting up some historical context. Orlando moves towards shifting away from historical and sociological approaches to introducing « case studies » of artworks and analysis, succeeding in making a welcome contribution to the body of existing literature.

Theoretically strong with a firm underpinning of research Orlando showcases a vast number of writers, thinkers, curators and artists, while also managing to remain accessible. Acknowledging the limitations of the book length, Orlando's extensive research serves to regularly offer signposts for the reader to further investigate otherwise under documented events and activities. This book will be an invaluable source for both students and teachers of a range of subjects such as fine art, photography and film, art history, media studies, visual culture, history, cultural studies, feminisms and more.

\section{NOTES}

1. Sophie orlando, British Black Art: Debates on Western Art History, Translated from French by Charles La Via, Paris, Dis Voir, 2016.

2. The term Black Arts Movement, like the period itself, does not have a fixed manifestation, another descriptor, for example, is 'British black arts movement', as described by Tate's online Art Terms glossary. I have, throughout this text, been consistent with Orlando's interpretation of the term/moment.

3. Kobena MERCER, 'Iconography after Identity', Shades of Black: Assembling Black Arts in 1980s Britain, ed. by David A. BAILEY, Ian BAUCOM, Sonia BOYCE (Durham \& London: Duke University Press, Iniva, Aavaa, 2005), p. 49-58, p. 50.

4. Sophie ORLANDO, op. cit., p. 11.

5. Ibid.

6. Ibid., p. 17 \& 7.

7. Stuart HALL, « Assembling the 1980s: The Deluge - and After », BAILEY et al (ed.), Shades of Black, p. $1-20$, p. 2.

8. K. MERCER, Shades of Black, p. 53.

9. S. ORLANDO, op. cit., p. 13.

10. Ibid., p. 13.

11. Ibid., p. 15.

12. Ibid., p. 7.

13. Ibid., 'Chapter I: British Black Art', p. 17-42.

14. Here I use the idea of histories being folded out of sight in direct reference to British art historian Jenny Tenant Jackson's essay considering the folds of art history: Jenny Tennant 
Jackson, 'The Efficacity of Meta-Conceptual Performativity: Or, we just do not know what we are talking about', Conceptual Odysseys: Passages to Cultural Analysis, ed. by Griselda Pollock (London \& New York: I. B. Tauris, 2007), p. 153-71.

15. S. ORLANDO, op. cit. 'Chapter II - Deconstructing and Rethinking the Positions of $20^{\text {th }}$ Century Western Art', p. 43-64, p. 43.

16. Gilane TAWADROS, 'Beyond the Boundary: The Work of Three Black Women Artists in Britain', Third Text, 8 (1989), p. 121-150.

17. Ibid., p. 49.

18. Ibid., 'Chapter III - Artistic Tactics and New Internationalism', p. 65-93.

19. Ibid., p. 65.

20. Ibid., p. 82.

21. Ibid., Chapter IV: Political Cultures of the British Artistic Scenes, p. 94-115.

22. Ibid., p. 111.

23. Ibid., p. 115.

24. Ibid., p. 17.

25. Members of the Blk Art Group included Eddie Chambers, Claudette Johnson, Keith Piper, Donald Rodney and Marlene Smith. They organised the First National Black Art Convention at Wolverhampton Polytechnic in 1982.

26. Forthcoming publications in this field include: Celeste-Marie BERNIER, Stick to the Skin: Representing the Body, Memory, and History in Fifty Years of African American and Black British Art (1965-2015), University of California Press; and Anjalie DALAL-CLAYTON, Curating Black British Art: Exhibition Cultures Since the 1980s, I.B.Tauris (an imprint of Bloomsbury). Leon WAINWRIGHT, Phenomenal Difference: A Philosophy of Black British Art, Liverpool University Press, 2017, had not been published at the time of writing this review.

27. Eddie CHAMBERS, Black Artists in British Art: A History Since the 1950s (London: I.B. Tauris, 2014).

\section{ABSTRACTS}

Ella S. Mills explores new approaches in Art History, based on intersectional feminism, reviewing Sophie Orlando's British Black Art: Debates on Western Art.

\section{INDEX}

Keywords: Contemporary art, Black Art, Great Britain

\section{AUTHOR}

\section{ELLA S. MILLS}

Dr Ella S. Mills is an Art Historian based in South West England whose research focuses on the work of British artists Sutapa Biswas, Sonia Boyce, Lubaina Himid, Claudette Johnson, Ingrid Pollard and Maud Sulter. She is also developing new approaches to Artist Interviews based on her 
'methodology of listening' which draws on qualitative elements of grounded theory. She is currently a Post-Doctoral Researcher undertaking Artist Interviews with the AHRC Black Artists and Modernism project led by Sonia Boyce. She is also a resident of Kaleider, an arts organisation based in Exeter which brings people together to design, create and produce art and live experiences.@LivingArchives @kaleider @AHRC_BAM 